\title{
要素間相互作用にカオスが内在する 複雑システムのための動的離隔型設計法*
}

\author{
中山 功一 $\dagger$ ・下原 勝憲 $\dagger \cdot$ 片井 修
}

\section{Dynamically Separating Design Method for Complex System including Chaos*}

Koichi NAKAYAMA ${ }^{\dagger}$, Katsunori ShIMOHARA ${ }^{\dagger}$ and Osamu KATAI ${ }^{\ddagger}$

In this paper we discuss a system design method that involves the dynamic separation of interaction. Multi-agent systems, which model the ubiquitous computing environment where elements behave autonomously, are used as the experimental platform to compare the proposed method with traditional ones. The results show the effectiveness of this design method for systems including chaos.

\section{1.はじめに}

システムを設計する場合，システムのすべてを事前に 設計するのではなく，システムの一部を事後的・適応的 に設計する方法が研究されている [1]. 本論文では, 複雑 なシステムの事後適応的な設計法の一つとして, 要素間 相互作用の動的離隔を内包する設計法（動的離隔型設計 法）について述べる.

システムの外部環境や内部の挙動が確定的で事前に予 測可能な場合, システムの設計が適切であるかを事前に 判定できるため，事前設計が有効である。一方，これら が不確定な場合や事前に予測が困難な場合, システムの 設計が適切であるかを事前に判定できないため, 事後適 応的な設計法との組合せが有効である（Fig. 1). たとえ ば，システムを構成する個々の要素に計算機資源が偏在 する “ユビキタス・コンピューティング”とよばれる環 境では, 各コンピュータの状態が可変であり, 要素の追 加・変更が頻繁である場合がある。このため, システム の挙動のすべては事前に予測が困難であり，事前設計が 難しい. 一方, 個々のコンピュータの自律適応的な振舞 いは可能であるため, 事後適応的な設計法の適用は可能

*原稿受付 2005 年 3 月 14 日

† ATR ネットワーク情報学研究所 ATR Network Informatics Laboratories; 2-2-2 Hikaridai, "Keihanna Science City", Kyoto 619-0288, JAPAN

‡京都大学大学院 情報学研究科 Graduate School of Engineering, Kyoto University; Yoshida-Honmachi, Sakyo ward, Kyoto city, Kyoto 606-8501, JAPAN

Key Words: dynamic separation, chaos, complex system, emergent design, ubiquitous computing.

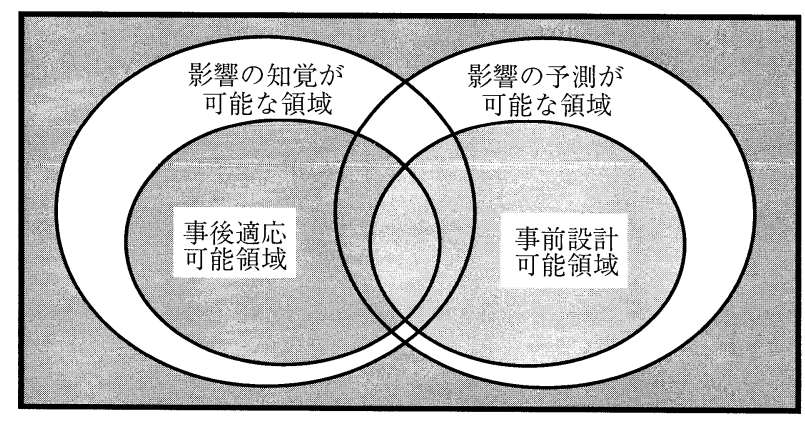

Fig. 1 Applicable areas of prior design and adjustment design

である。

事後適応的な設計では, 各要素が全体システムへ与え る影響を知覚し，適切な挙動を適応的に決定する。しか し，各要素が全体システムへ与える影響を知覚できず， その要素の挙動がシステムにとって適切であるか判定で きない場合, システムにとって適切な要素の挙動の決定 は困難である。すなわち，事後適応的な設計法が適切に 機能するためには，システムを構成する各要素が全体シ ステムに与える影響を知覚・検出する必要がある。

近年の大規模で複雑なシステムでは, 個々の要素が全 体システムに与える影響や要素間相互作用の予測や知覚 は必ずしも容易ではなく, 従来の事後適応的な設計法で は適切なシステムの設計が困難である場合がある。本論 文では，要素間相互作用の予測や知覚が困難であるよう な複雑システムの事後適応的な設計法として, システム を構成する要素間の相互作用を動的離隔により操作する 
動的離隔型設計法について議論する．本設計法の性質を 明らかにする実験モデルとして，システムを構成する要 素を自律適応的なエージェントとして，各要素が全体シ ステムへ影響を与える挙動をエージェントの行動として モデル化するマルチエージェントシステム $[2,3]$ (以下， MAS と記す）を用いる。また，予測困難な要素間相互 作用を，カオスとなるロジスティック方程式としてモデ ル化し，エージェントの事後適応的な学習によるシステ ムの適切な設計を実現する。

本論文の構成は以下のとおりである，2 章で，動的離 隔型設計法と, 検証に用いる実験モデルについて述べる. 3 章で，要素間相互作用の知覚や動的離隔が可能である モデルを用いて，提案する要素間相互作用を離隔する設 計法（動的離隔型設計法）を，従来の要素間相互作用を 知覚する設計法と実験的に比較し，それぞれの設計法が 有効な対象領域を明らかにする.4 章で, 要素が全体シ ステムに与える影響の予測や知覚が困難なシステムのモ デルとして，要素間相互作用にカオスが内在する実験モ デルを用いて，動的離隔型設計法の有効性を検証する。 5 章で，まとめと今後の課題を述べる.

\section{2. 動的離隔型設計法}

\section{1 設計法の導入}

動的離隔型設計法は, MASにおけるエージェントの学 習手法の一つである動的離隔型遺伝的アルゴリズム $[4,5]$ を，カオスが内在するシステムの設計に応用するもので ある。

動的離隔型設計法では, 各エージェントは, 相互作用 するエージェントの限界数を持ち，コロニーとよぶグ ループごとに離隔される（Fig. 2)．異なるコロニーに存 在するエージェントとは相互作用しない. 同一コロニー 内に存在するエージェント数が増加し限界数以上にな る場合，そのコロニーに存在するエージェントは，さら に半数ずつのコロニーに離隔される（Fig. 3 上）. エー ジェント数が 0 になる場合, そのコロニーを消滅させる (Fig. 3下).

システムを設計する場合，すべてを事後適応的に設計

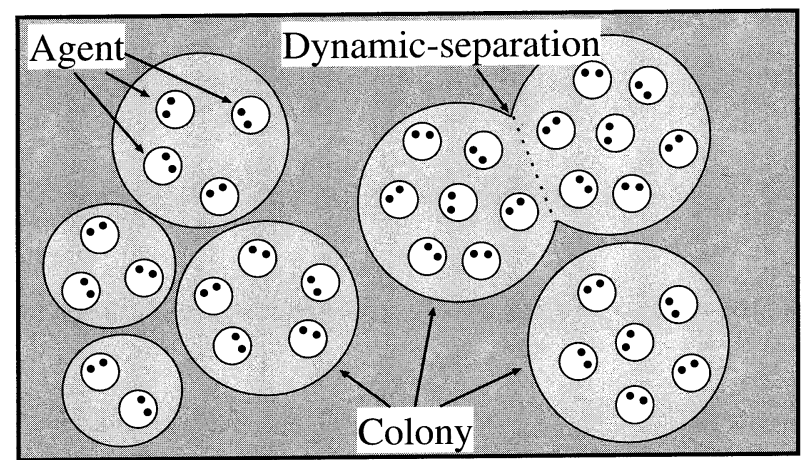

Fig. 2 Conceptual representation of dynamically separating design method

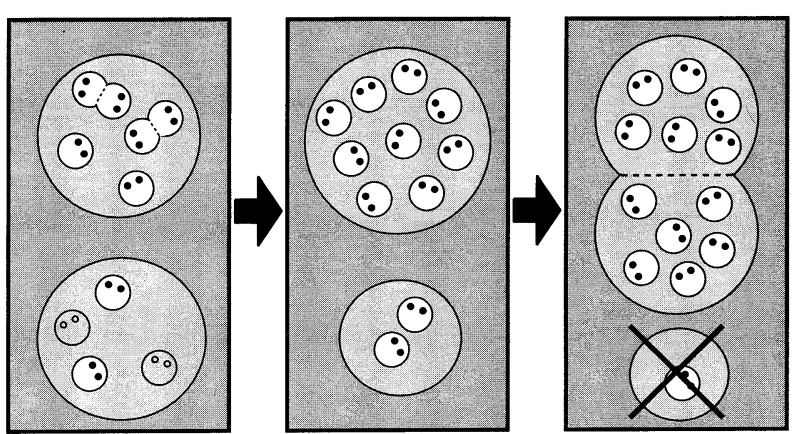

Fig. 3 Transformation of colonies by dynamic separation

するのではなく，事前設計と事後適応の適切な組合せが 重要である。このとき，システムにおいて事後適応する 部分, すなわち, 学習するエージェントとしてモデル化 される部分にとって, 事前に設計された部分は適応すべ き環境の一部である. 本論文では, 事後適応的な設計法 に注目して議論するため, MASにおいて事前に設計さ れたエージェント（学習しないエージェント）や，他に 影響を与えないエージェント（行動しないエージェント） は，考えないものとする。

\section{2 実験モデルの導入}

設計すべき対象のモデルとして, エージェントの挙動 を決定する構造や出力などの設計を, エージェントの行 動の選択として置き換えた行動選択モデルを用いる。ま た，エージェントの行動により全体システムや他のエー ジェントに与えるすべての影響を, システムの目的に対 する貢献度を示すパラメータである自己評価值の増減と してモデル化する。

エージェント $a$ が受ける影響は, すべて自己評価值 $E_{S}(a, t)$ の増減として表される. MAS 全体にとって適 切な行動とは, すべてのエージェントが受ける影響の総 和, すなわち, 自己評価值の総和を最大化する行動であ る。また，エージェント $a$ が他のエージェントに与える 影響のうち, エージェント $a$ が知覚する影響は, 他者評 価值 $E_{O}(a, t)$ の増減として表される.

\section{3 行動学習アルゴリズム}

一般的に事後適応的に設計される対象は, ハードウエ ア部分ではなくソフトウエア部分である場合が多い。こ こでは, エージェントの自律性を損なわない学習アルゴ リズムとして，自己評価值と他者評価值の和に基づく エージェントの分裂と消滅を用いる。

本論文で用いる実験モデルのメインルーチンを NS チャートでFig. 4 に，詳細を以下に示す.

（1）初期設定：仮想環境内に，100000 個体のエージェン トを作成する，個体は，自らの受ける影響を示す自 己評価值 $E_{S}(a, t)$ (初期值 100）と, 自らの知覚でき る範囲で与えた影響を示す他者評価值 $E_{O}(a, t)$ （初 期值 0), 選択する行動を示す戦略 $S t(a)$ （初期值無 作為）を持つ. 各個体を限界数 $\operatorname{Lim}_{a}=10$ ごとの 


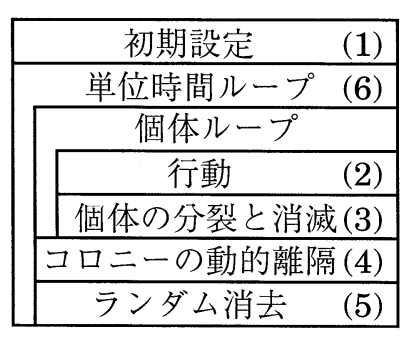

Fig. 4 Main routine of dynamically separating design method shown by NS chart

コロニーに離隔する。

(2) 行動：全個体が, それぞれの戦略に従い 1 回ずつ行 動を選択する行動選択モデルを用いる．行動により 自己評価值および他者評価值が増減する，詳細は実 験ごとに異なるため, 3 章および 4 章で述べる.

（3）分裂と消滅：分裂は, 個体の自己評価值と他者評価 值の和が初期值の倍 $(200)$ 以上になると起きる。こ のとき，個体は，分裂前の各評価值を半分ずつ持つ 2 個体に分裂し，それぞれ戦略を引き継ぐ。消滅は, 個体の各評価值の和が 0 以下になると起き，個体が 消滅する.

（4）コロニーの動的離隔：コロニーの動的離隔は，コロ ニー内の個体が限界数 $\operatorname{Lim}_{a}=10$ を超えると起き る.このとき，一つのコロニー内に存在する個体は， 二つのコロニーに無作為に離隔される.

(5) ランダム消去：個体総数が初期個体数より増えた場 合，個体総数が初期個体数以下になるまで個体を無 作為に消去する.

(6) 単位時間ループ: (2)〜 (5)を繰り返す。これを 1 単 位時間とし，これに基づく時刻を $t$ で表す.

このアルゴリズムは, 個体の増加が各評価值の増加に 比例し，個体の消去が無作為であるため，各評価值に基 づくルーレット選択による進化的オペレータと近い性質 を持つ.

なお，本設計法は，コンピュータ・シミュレーション などを用いることで，自律適応的な要素からなるシステ 厶の事後適応的な設計のみならず，自律適応性の無い要 素からなるシステムの予備設計にも適用可能である。ま た，本設計法における動的離隔を実現する方法は，適用 対象に応じて様々である．たとえば，エージェントが無 線ネットワークを通じて相互作用するシステムでは，動 的離隔はエージェントが通信に用いるチャネルの操作に

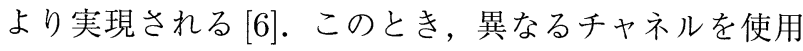
するエージェントとは相互作用がなく, 同一チャネル内 エージェントの半数が使用チャネルを変更することで, そのチャネル内エージェントは二つのチャネルに動的離 隔される。また，エージェントがログインなどの手続き により接続されるシステムでは, 動的離隔は認証管理者 による操作により実現される [7].このとき，エージェ ントの所属するコロニーは認証管理者により決定され，
相互作用はコロニー内に制限される。認証管理者がコロ ニー内エージェントの半数の所属を別のコロニーに変更 することで，そのコロニー内エージェントは二つのコロ ニーに動的離隔される.

\section{3. 設計法の比較検証}

本章では，要素間相互作用にカオスを含む MAS に対 する性質を明らかにする前に，要素間相互作用を知覚す る設計法の性質と離隔する設計法の性質を実験的に比較 検証する。

\section{1 行動選択モデル}

MAS におけるタスクの実行や問題解決などの行動 は, 複数のエージェントの行動選択問題としてとらえ られる $[8]$. 本実験では, エージェントが単位時間ごと に 3 種類の行動 $(A, B, C)$ から一つを選択する行動選 択モデルを用いる。エージェント $a$ が選択した行動に より影響を受けるエージェントは, 以下に示す 3 種類 $a, x, Y=\left\{y_{1}, y_{2}, y_{3}, y_{4}, y_{5}\right\}$ とし, それぞれ行動ごとに選 択される。

(1) 第一者 $(a)$ ：ある行動をする行為者である. 単位時 間ごとに全エージェントが第一者として 1 回ずつ行 動する，自らの行動により，自らの自己評価值が増 減する.

(2) 第二者 $(x)$ ：第一者の行動による影響を, 直接的に 受ける被行為者である. 直接的で予測や知覚が比較 的容易な影響のモデルとして，第二者として無作為 に選択された 1 個体の自己評価值が，第一者の行動 と同時に増減する。

(3) 第三者 $(Y)$ : 第一者の行動およびその相互作用によ る影響を, 間接的に受ける被影響者である. 間接的 で予測や知覚が比較的困難な影響のモデルとして， 第三者として無作為に選択された 5 個体のすべての 自己評価值が 10 単位時間後に増減する。 なお，本実 験モデルでは，エージェントの分裂には $10 〜 20$ 単 位時間が必要である。このため, 10 単位時間後の影 響とは，過半数のエージェントにとって次の世代の エージェントに与える影響であり，予測や知覚の困 難な影響であることを意味する。

エージェント $a$ は, 自らの行動を決定する戦略 $(S t(a) \in$ $\{A, B, C\})$ を持つ. 単位時間ごとに, 自らの戦略に従い行 動 $(A c t(a, t)=S t(a))$ を選択する.このとき, エージェン トの行動に関して全体システムに与える影響とエージェ ントの受ける影響が等価である場合，自らの受ける影響 に基づいた学習と全体システムに与える影響に基づいた 学習が等価になり，学習において他のエージェントに与 える影響の知覚も離隔も必要ない。一般的には，これら は必ずしも一致せず，いわゆるジレンマ環境 $[9,10]$ とな る.そこで，これらが異なるモデルとして，第一者である エージェント $a$ の時刻 $t$ における行動 $\operatorname{Act}(a, t)$ により第 
一者 $a$ ，第二者 $x$ ，第三者 $Y=\left\{y_{1}, y_{2}, y_{3}, y_{4}, y_{5}\right\}$ がそれぞ れ受ける影響 $I_{a}(\operatorname{Act}(a, t)), I_{x}(\operatorname{Act}(a, t)), I_{Y}(\operatorname{Act}(a, t))$ をTable 1 のように設定する。また，行動による自己評 価值の変化を $(1)$ に示す.

Table 1 Increase and decrease of self-evaluation value by selected actions

\begin{tabular}{c|l|c|c|c}
\hline Act $(\mathrm{a}, \mathrm{t})$ & 第一者 $(\mathrm{a})$ & 第二者 $(\mathrm{x})$ & 第三者 $(\mathrm{Y})$ & 総和 \\
\hline $\mathrm{A}$ & $\mathrm{I}_{\mathrm{a}}(\mathrm{A})=10$ & $\mathrm{I}_{\mathrm{x}}(\mathrm{A})=0$ & $\mathrm{I}_{\mathrm{Y}}(\mathrm{A})=-1$ & 5 \\
$\mathrm{~B}$ & $\mathrm{I}_{\mathrm{a}}(\mathrm{B})=5$ & $\mathrm{I}_{\mathrm{x}}(\mathrm{B})=7$ & $\mathrm{I}_{\mathrm{Y}}(\mathrm{B})=-1$ & 7 \\
$\mathrm{C}$ & $\mathrm{I}_{\mathrm{a}}(\mathrm{C})=0$ & $\mathrm{I}_{\mathrm{x}}(\mathrm{C})=0$ & $\mathrm{I}_{\mathrm{Y}}(\mathrm{C})=2$ & 10 \\
\hline
\end{tabular}

$$
\begin{aligned}
E_{S}(a, t+1) & =E_{S}(a, t)+I_{a}(\operatorname{Act}(a, t)) \\
E_{S}(x, t+1) & =E_{S}(x, t)+I_{x}(\operatorname{Act}(a, t)) \\
E_{S}(Y, t+11) & =E_{S}(Y, t+10)+I_{Y}(\operatorname{Act}(a, t))
\end{aligned}
$$

本論文で用いる行動選択モデルでは，第一者の自己評 価值にとっては行動 $\mathrm{A}$ が最も適切である（個体最適行 動)．第一者と第二者の自己評価值にとっては行動 B が 最も適切である (局所最適行動)。すべての第三者への 影響も含めた MAS 全体の自己評価值の総和にとっては 行動 C が最も適切である (全体最適行動)．影響の知覚 に基づく他者評価值の増減は手法ごとに異なるため, 次 節で述べる。

\section{2 知覚による設計}

本章では，個体が自らの行動により他者に与える影響 を知覚し，他者により良い影響を与える行動の学習によ り，MAS 全体にとって適切な行動を獲得するシステム の設計法について述べる. 実験は，知覚する範囲が異な る 3 種類とする.

(1) 無知覚モデル：自らの行動が他者に与える影響を知 覚しないモデル。他者評価值はつねに0である。

$$
E_{O}(a, t)=0
$$

(2) 第二者知覚モデル：自らの行動が第二者に与える影 響を知覚し，他者評価値に加えるモデル．他者評価 值は下式に従い変化する。

$$
E_{O}(a, t+1)=E_{O}(a, t)+I_{x}(A c t(a, t))
$$

(3) 全知覚モデル：自らの行動が第二者，およびすべて の第三者に与える影響を知覚し，他者評価值に加え るモデル．他者評価値は下式に従い変化する。

$$
\begin{aligned}
E_{O}(a, t+1) & =E_{O}(a, t)+I_{x}(\operatorname{Act}(a, t)) \\
& +\sum_{k=1}^{5} I_{y_{k}}(\operatorname{Act}(a, t-10))
\end{aligned}
$$

本節の実験では，いずれのモデルにおいても，影響の 離隔は用いない. すなわち, 第二者, およびすべての第 三者はすべてのコロニーから無作為に選択する。このた め, アルゴリズムにおける「(4)コロニーの動的離隔」を 実行しない場合や, 集団数が 1 である場合（限界個体数 $\geq$ 個体数) と等しい.

\subsection{1 実験結果}

各実験モデルにおける単位時間あたりの自己評価值の 平均増加量の推移を Fig. 5 に, 戦略別個体数比率の推移 を Fig. 6 に示す.

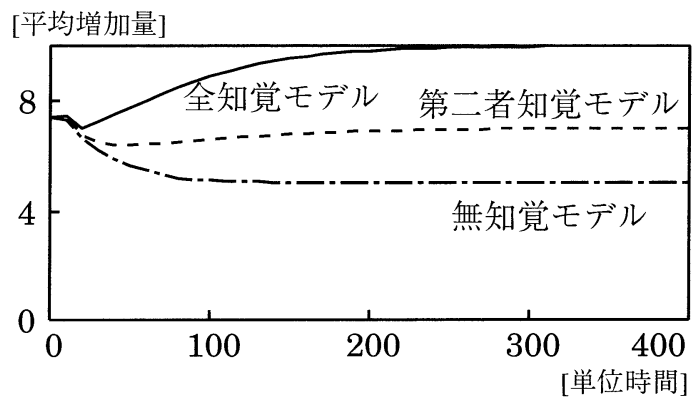

Fig. 5 History of the amount of an average increase of self-evaluation value in each experimental model
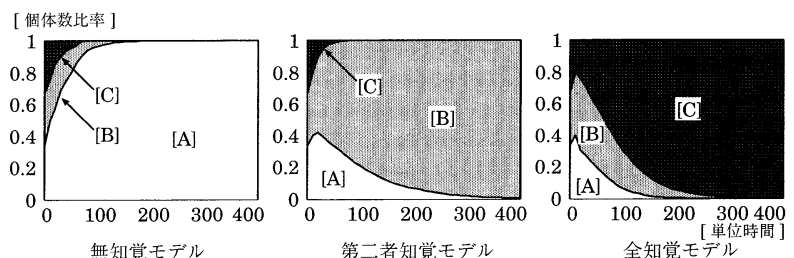

Fig. 6 History of the popuration ratio of strategies in each experiment model

無知覚モデルでは，すべての個体が個体最適な行動 $\mathrm{A}$ を学習した．第二者知覚モデルでは，すべての個体が局 所最適な行動 $\mathrm{B}$ を学習した。全知覚モデルでは,すべて の個体が全体最適な行動 Cを学習した。

要素間相互作用を知覚する設計法では, 各個体は, 自 らの知覚できる範囲において最も適切な行動をそれぞれ 学習した。また，第三者への影響を，第一者の行動から 30 単位時間後，および 100 単位時間後に変更して実験し たところ，学習により多くの時間を必要としたが，学習 結果には変化がなかった。これらの結果から，各個体が 自らの行動により全体システムに与えるすべての影響を 知覚できれば，この設計法で全体システムにとって最適 な挙動を設計できるといえる。このとき，“適切に設計 できる対象”は，“影響を知覚できる対象”に含まれる といえる。

\section{3 離隔による設計 \\ 3.3.1 実験モデル}

本章では，第一者が自らの行動により他者に与える影 響を離隔し学習することで, MASにとって適切な行動 
を獲得するシステムの設計法について述べる，実験は， 影響の離隔が異なる 3 種類とする.

(1) 無離隔モデル：個体の行動が他者に与える影響を離 隔せずに学習するモデル．第二者とすべての第三者 は, すべてのコロニーから無作為に選択される.

（2）第二者離隔モデル：個体の行動による直接的な影響, すなわち，第二者に与える影響を同一コロニー内に 離隔し学習するモデル。第三者へ与える影響は離隔 しない. 第二者は，第一者の所属するコロニーから， すべての第三者はすべてのコロニーから無作為に選 択される.

(3) 全離隔モデル：個体の行動によるすべての影響，す なわち，第二者，拉よびすべての第三者に与える影 響を同一コロニー内に離隔し，学習するモデル．第 二者とすべての第三者は，第一者の所属するコロ ニーから無作為に選択される.

本節の実験では, いずれのモデルにおいても影響の知 覚は用いない。すなわち，他者評価值はつねに 0 とする.

\subsection{2 実験結果}

各害験モデルにおける単位時間あたりの自己評価值の 平均増加量の推移を Fig. 7 に, 戦略別個体数比率の推移 をFig. 8 に示す.

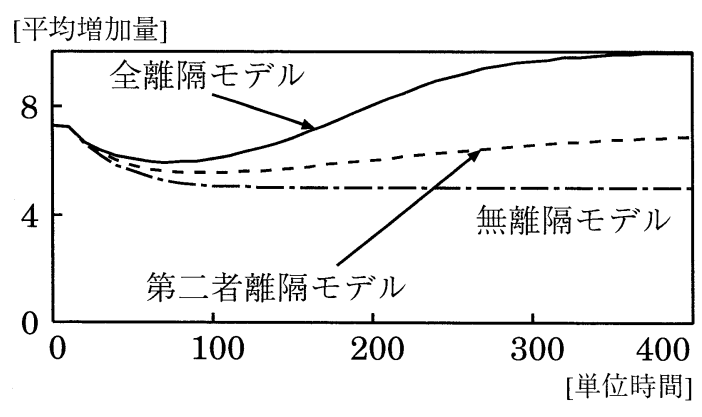

Fig. 7 History of the amount of an average increase of self-evaluation value in each experimental model
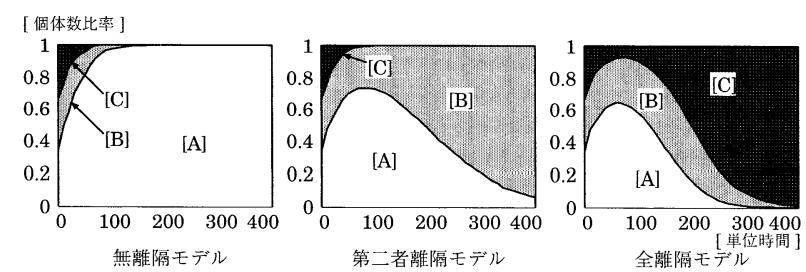

Fig. 8 History of the popuration ratio of strategies in each experiment model

無離隔モデルでは，すべての個体が個体最適な行動 $\mathrm{A}$ を学習した．第二者離隔モデルでは，すべての個体が局 所最適な行動 B を学習した。全離隔モデルでは, すべて の個体が全体最適な行動 Cを学習した。

要素間相互作用を離隔する設計法では, 各個体は, 他 個体や MAS 全体の評価值を増加させるメカニズムは持 たない。また，他個体の自己評価値を直接的には知覚し
ない，ところが, 各個体は, 自らの行動による影響が離 隔される範囲に扔いて, 最も自己評価值の総和が大きい 行動をそれぞれ学習した。 このメカニズムは, 以下のよ うであると考元られ、いずれのコロニーに㧍いても， 行動 $\mathrm{C}$ 上り行動 B を, 行動 B より行動 A を選択する個 体の自己評価值の増加量が大きく, より速く分裂する。 これは, 個体の知覚に基づく学習である. 一方, 行動 A より行動 B を, 行動 B より行動 C を選択する個体の多 いコロニーほど, コロニー内の自己評価值の総和の増加 量が大きく, より速く動的離隔する。これは, 集団とし ての知覚に基づく学習である。これらの学習の組合せに より, 個体がコロニー内の自己評価值の総和を間接的に 知覚する機能が創発し, 離隔された範囲内に扔いて最も 自己評価值の総和が大きい行動を学習する (付録参照). これは, 単純な知能を持つ個体が集団となることで創発 してくる知能と定義される群知能 [11] の一種であると いえる. 本論文では, これ以降, 単純な知覚を持つ個体 が集団となることで創発してくる知覚を，＜群知覚〉と よぶ.

な㧍，第三者への影響を，第一者の行動から 30 単位 時間後, および 100 単位時間後に変更して実験したとこ ろ, 学習により多くの時間を必要としたが, 学習結果に は変化がなかった。これらの結果から, 各個体の行動に よるシステムへの影響がすべて離隔できれば, 群知覚に より全体最適性は得られると考えられる。この設計法で は, “適切に設計できる対象”は, “影響を動的離隔でき る対象”に含まれるといえる.

\section{4 考察}

二つの異なる設計法を用いた実験結果から，それぞれ 影響を知覚，または離隔する範囲内に打いて，それぞれ 適切な行動を獲得した。これらの結果から, 従来の影響 を知覚する設計法が適用困難な環境であれば, 影響を離 隔する設計法を用いることで, 知覚する設計法と同様の 結果を得られると考えられる。

一般に, すべての相互作用の知覚や, すべての相互作 用の離隔は, 必ずしも可能であるとはいえない. 相互作 用を知覚できる対象の設計と, 離隔できる対象の設計は, 異なるクラスの問題である。ここで, 従来の他個体への 影響を知覚する設計法では, “適切に設計できる対象” は, “影響を知覚できる対象”に含まれる。すなわち,こ れまでの設計法では, 要素が全体システムへ与える影響 を知覚できない場合, システムの適応的な設計は困難で あった。しかし，提案した他個体への影響を動的に離隔 する動的離隔型設計法では, “適切に設計できる対象” は, “影響を動的離隔できる対象”に含まれる（Fig. 9）. これは, 従来の設計法では要素が全体システムへ与える 影響を知覚できないため設計が困難であった複雑システ ムでも, 提案する動的離隔型設計法によりシステムの適 応的な設計が可能となる場合があることを示す. 動的離 


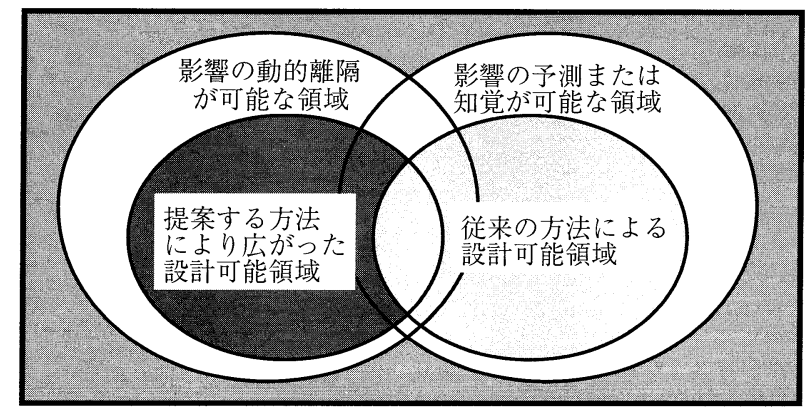

Fig. 9 Applicable areas of dynamically separating design method and traditional methods

隔型設計法により，新たに設計可能な領域が広がったと いえる.

それぞれの手法により設計されるシステムは，それぞ れ以下のような特徴を持つと考えられる．従来の知覚に 基づく方法論では, 要素の行動による影響を知覚できる ようシステムを構成する必要があるため, 複数の要素が 互いにできるだけ相互作用しないよう独立したモジュー ルとして設計される。これは，事前設計においても，要 素間の影響を予測できるようシステムを構成する必要が あるため同様である。しかし，提案する動的離隔型設計 法では, 複数の要素が相互に影響する場合でも, その影 響の動的な離隔が可能であれば設計可能である。このた め, 要素間の関係にカオスやバタフライ効果が内在して いる場合でも，その影響を動的に離隔できれば，システ ムの適切な設計が可能であると考えられる.

\section{4. カオスが内在するシステムの設計}

前章までにおいて, 要素間相互作用を動的に離隔する 設計法のメカニズムと, その基本的な性質を明らかにし た。本章では, 要素間相互作用の予測と知覚が困難なシ ステムの例として，カオスが内在するシステムを離隔に よる方法を用いて設計し，その性質を議論する。

\section{1 行動選択モデル}

要素のある挙動が与える影響が挙動ごとにランダムに 決定される場合のように, 要素間相互作用に再現性がな い場合は, システムにとって適切な要素の挙動や構造の 事前設計は不可能である。また, 要素間相互作用の予測 や知覚が容易な場合, システムにとって適切な要素の挙 動や構造は従来法により容易に設計できる.すなわち, 本論文で述べる動的離隔型設計法が有効な対象は, 要素 間相互作用に再現性はあるが，その予測や知覚が困難な システムである。

本章では，上記のように再現性はあるが個々のエー ジェントにとって予測や知覚が困難な行動モデルの例と して, 要素間相互作用にロジスティック方程式で表され るカオスを用いる.ここで, ロジスティック方程式は, 予 測不可能性のモデルであり，行動に対する影響の再現性 は保証されるものとする。
エージェント $a$ の行動 $A c t(a, t)$ は, 自らの戦略 $S t(a) \in$ $\{0,0.02,0.04, \cdots, 0.98,1\}$ に従い決定する $(A c t(a, t)=$ $S t(a))$. 行動したエージェント $a$ は, 自らの行動と 同時に(5) 式に従い影響を受ける。また，エージェント $a$ の行動は, 20 単位時間にわたり, 単位時間ごとに同一 コロニー内から無作為に選ばれた他のエージェント $r$ に 対し (6) 式に示すロジスティック方程式に従い影響を与 える。なお，20 単位時間後の影響とは，ほとんどのエー ジェントにとって次の世代に与える影響であり, 予測や 知覚の困難な影響であることを意味する.

$$
\begin{aligned}
& E_{S}(a, 0)=\operatorname{Act}(a, 0) \\
& E_{S}(r, t+1)=X \times E_{S}(r, t) \times\left(1-E_{S}(r, t)\right)
\end{aligned}
$$

ここで, $X$ は, 時間経過と共に影響の予測や知覚が困難 となるように, $E_{S}(r, t)$ の值が収束や周期倍分岐ではな くカオスとなる $X=4$ とする.すなわち, エージェント の行動は， $X=4$ である (6) 式の初期值である.このと き, エージェントにとって行動による影響が知覚不可能 であるモデルとして，エージェントは，自らの行動によ りどのエージェントに影響を与えたのかを知覚できず, 自らの受けた影響がどのエージェントの行動によるもの かを知覚できないものとする.

20 単位時間にわたり, エージェントの行動によりすべ てのエージェントが受ける影響の総和，すなわち，自己 評価值の総和を Fig. 10 に示す. 行動 [0.88] が与える自己 評価值の総和が最も高い.

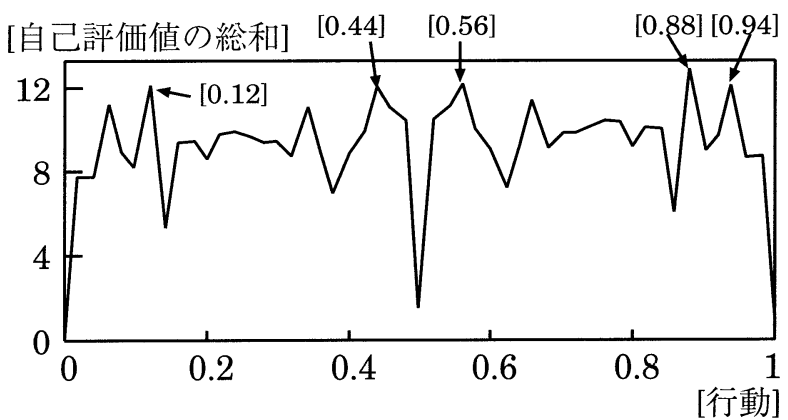

Fig. 10 Total of influence in the whole system by each action

\section{2 実験結果と考察}

行動 [0.88] の場合を 1 として正規化した単位時間あた りの自己評価值の平均増加量の推移を Fig. 11 に, 戦略 別個体数比率の推移を Fig. 12 に示す. 全体システムの 評価值の最も高い行動を獲得したことがわかる.これは, エージェントが，影響が動的離隔される範囲内で最も評 価值の高い行動を群知覚により学習したためである.

また，(6) 式における $X$ の值を, $E_{S}(r, t)$ の值が収束 する $0 \leq X \leq 3$ や周期倍分岐となる $3<X<3.57$ とした 


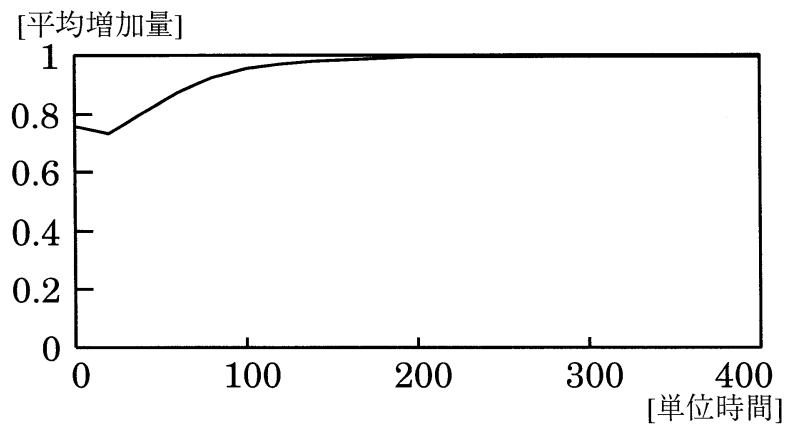

Fig. 11 History of the amount of an average increase of self-evaluation value

[ 個体数比率]

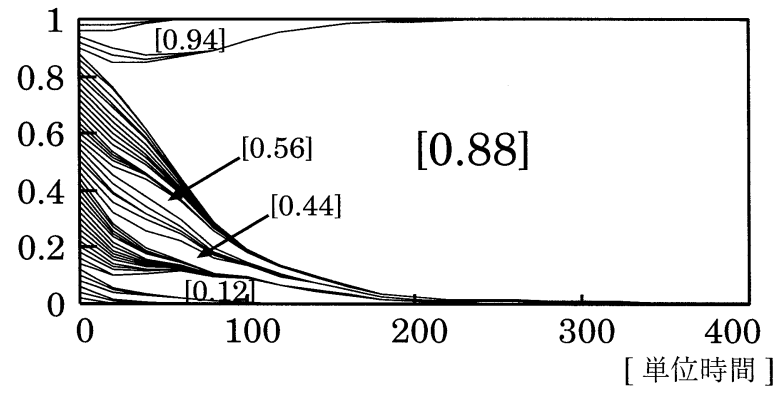

Fig. 12 History of the popuration ratio of strategies

場合に扔いても，本章で用いた $X=4$ の場合で得られた 結果と同様に，全体システムにとって最も評価値が高い 行動を獲得した。さらに，本章の行動モデルに抢ける要 素間相互作用を，ロジスティック方程式により決められ た值ではなく，周期的な值やランダムに決定した值を用 いた場合，あるいは，テントマップを用いた場合で実験 した結果も同様に，全体システムにとって最も評価値が 高い行動を獲得した。これは，動的離隔型設計法では， 要素間相互作用がどのように決定される場合においても， 影響が動的離隔される範囲内で最も評価值の高い行動を 群知覚により獲得できるためである.

これらの結果から，システム設計に扔いて，要素間相 互作用に再現性があり，コロニーに動的離隔できる場合 には，要素間相互作用を個々の要素が知覚できず，シス テム設計者が検出できない場合でも, 群知覚により全体 システムにとって適切な要素の事後適応的な設計が可能 であるといえる。

\section{5. おわりに}

本論文では, 多数の要素からなるシステムの事後適応 的な設計法の構築に向け, 要素間相互作用を動的に離隔 する動的離隔型設計法について実験的に検証した。実験 結果から，要素の挙動による影響を動的に離隔すること で, 要素が全体システムや他の要素に与える影響を知覚 する必要なく, 全体システムにとって適切な挙動を獲得 した。また，要素レベルでは知覚できない全体システム の最適性を集団レベルで知覚する現象が創発しており，
これを群知覚と定義した。

従来の一般的な設計法による設計には要素間相互作用 の知覚が必要であり，人による事前設計には要素間相互 作用の予測が必要である。これに対し，提案した動的離 隔型設計法によるシステム設計には，要素間相互作用の 離隔が必要である。要素間相互作用の離隔と知覚と予測 のうち，どれが容易でどれが困難であるかは設計するシ ステムによって異なるため，設計するシステムに応じた 方法の選択や，複数の設計法の組合せが重要である。し かし，本論文の結果から，システム設計に向けた新たな 方法が示されたといえる。

従来の事後適応的なシステム設計では, 要素が全体シ ステムにとっての最適性を知覚するメカニズムを持つ必 要がある。しかし, 動的離隔型設計法では, 動的離隔と いう環境操作に基づく群知覚により個体が全体最適性を 知覚するため, 個々の要素がこのメカニズムを持つ必要 がない。このため, 動的離隔型設計法は, 個々の要素に おける適応メカニズムの設計が容易であるという特徵を 持つ.また，設計者があらかじめ要素間の関係を明らか にする必要なく設計できるという意味で, システムの機 能を創発的に設計できる可能性が示唆される。

従来の方法で設計されたシステムでは，設計された時 点で要素間の相互作用が明示的である。一方, 動的離隔 型設計法では, 結果として全体システムが効率よく機能 する要素間の相互作用を獲得するため, システムの機能 がどの要素間のどのような相互作用により発現している かが必ずしも明示的ではなく, システムの機能が発現す るメカニズムが説明できない可能性がある。このため, これらのシステムが持つ機能の確実性や安全性の検証方 法などが今後の課題である。

\section{謝辞}

本研究は独立行政法人情報通信研究機構の研究委託 「人間情報コミュニケーションの研究開発」により実施 したものである。

\section{参考文献}

[1] ヤゼチプキン：学習システム入門，共立出版 (1973)

[2] M. Wooldridge: An Introduction to MultiAgent Systems, John Wiley and Sons Ltd (2002)

[3] 高玉：マルチエージェント学習一相互作用の謎に迫る, コロナ社 (2003)

[4] 中山, 松井, 野村: 動的離隔型 GA(DS-GA) の提案; 情報 処理学会論文誌：数理モデル化と応用（進化的計算特集 号) , Vol. 43, No. SIG 10 (TOM7), pp. 95-109 (2002)

[5] K. Nakayama, K. Shimohara and O. Katai: Dynamically separating GA: A new method of achieving the system-level optimality in MAS; The Journal of Three Dimensional Images, Vol. 16, No. 4, pp. 177$183(2002)$

[6] K. Nakayama, K. Shimohara and O. Katai: Pro- 
posal of Dynamically Separating Learning Algorithm (DS-LA): Optimization of collective performance in networked computers; The Journal of Three Dimensional Images, Vol. 18, No. 1, pp. 87-94 (2004)

[7] 中山, 松井, 下原, 片井: エージェント指向グリッドコン ピューティング (MAO-Grid) の提案とDS-GA の適用 によるロードバランシングの最適化; 情報処理学会論文 誌：数理モデル化と応用, 印刷中.

[8] 松原, 横尾: 繰り返しゲームにおいて協調行動を生成 する先読み型行動選択方法; 人工知能学会誌, Vol. 12, No. 6, pp. 881-890 (1997)

[9] R. Axelrod: The Evolution of Cooperation, Basic Books (1984)

[10] R. Axelrod: The Complexity of Cooperation, Princeton University Press (1997)

[11] E. Bonabeau, M. Dorigo and G. Theraulaz: Swarm Intelligence: From Natural to Artificial Systems, Oxford University Press (1999)

\section{付 録}

\section{付録 1. 群知覚の創発メカニズムの理解}

動的離隔により全体最適な行動を選択する個体が増 加するメカニズム，すなわち，3 章で定義した群知覚の メカニズムは, シンプソンのパラドックス (Simpson's paradox）と対比して考えると理解が容易になる.シン プソンのパラドックスとは，個々のサブ集団では成り立 つ仮説が集団全体では成り立たず，正反対の仮説が成立 する場合を意味する。たとえば，自己評価值の自らの増 加が 1 , 他者の増加が 0 である行動 $\alpha$ と, 自己評価值の 自らの増加が 0 , 他者の増加が 2 である行動 $\beta$ を仮定し, 行動 $\alpha$ が $90 \%$ を占めるコロニー 1 と, 行動 $\beta$ が $90 \%$ を 占めるコロニー 2 の二つを考える. いずれのコロニーに おいても, 自己評価值の増加量の平均は, 行動 $\alpha$ を選択 する個体の方が行動 $\beta$ を選択する個体より大きい. しか し，集団全体の平均では，行動 $\beta$ を選択する個体の方が 行動 $\alpha$ を選択する個体より大きい（Table A1）.

Table A1 Simpson's paradox

\begin{tabular}{c|c|c|c|c|c}
\hline & コロニー1 & 増加量 & コロニー2 & 増加量 & 平均 \\
\hline 行動 $\alpha$ & $90 \%$ & 1.2 & $10 \%$ & 2.8 & 1.36 \\
行動 $\beta$ & $10 \%$ & 0.2 & $90 \%$ & 1.8 & 1.64 \\
\hline 平均 & & 1.1 & & 1.9 & 1.5 \\
\hline
\end{tabular}

このとき, 集団を構成する戦略別個体数比率に偏りが 大きいほど行動 $\beta$ を選択する個体の増加量が大きい.す なわち, 動的離隔を用いる設計法では, 行動 $\mathrm{C}$ を選択す る個体が多く存在するコロニーが増加するというメカニ ズムに加え, 動的離隔によりコロニー内の個体の戦略に 偏りが発生するというメカニズムにより, 全体最適な行 動を選択する個体が知覚され, 増加する. 